American Journal of Applied Sciences 8 (9): 923-926, 2011

ISSN 1546-9239

(C) 2011 Science Publications

\title{
An Estimation of X-Radiation Output using Mathematic Model
}

\author{
Suchart Kothan and Montree Tungjai \\ Department of Radiologic Technology, Faculty of Associated Medical Sciences, \\ Chiang Mai University, Chiang Mai 50200, Thailand
}

\begin{abstract}
Problem statement: Diagnosis x-ray radiation safety is key in medical examination. The quantity of patient radiation doses is beneficial for radiation protection of the patient. It was proposed that the equation for estimating the output (milliReongent, $\mathrm{mR}$ ) from $\mathrm{x}$-ray machines. Approach: A was $0.5,0.8$ and 1.0 for single phase, three phases and high frequency $\mathrm{x}$-ray machines, respectively. To compare calculated output $(\mathrm{mR})$ used this equation and measured output $(\mathrm{mR})$ used ionizing chamber dosimeter. Results: The difference between the calculated and measured radiation dose was quite small. Conclusion: This equation could use to estimate output and it altered the reliable and inexpensive techniques for patient dose measurement in routine diagnostic $\mathrm{x}$-ray examinations.
\end{abstract}

Key words: Radiation output, Ionization Chamber (IC), x-ray machine, radiation dose, calculated radiation

\section{INTRODUCTION}

Radiology is widely used for the evaluation of various kinds of diseases. There are reports showing low doses of radiation exposure encountered in diagnostic $\mathrm{x}$-ray radiation may induce malicious conditions. Tahara and Kaneko (2004) reported the survival rate in splenic cells in BDF1 mice and fetal human lung fibroblasts TIG-7 irradiated with x-rays at dose of $1,2,5$ or $10 \mathrm{~Gy}$. The survival rate of both irradiated cells decreased in a dose-dependent manner. Survival of L02 cells decreased as the dose of x-ray increased and significantly higher levels of p53, bax, Fas and Fas-L protein were expressed in irradiated cells (Liu and Zhang, 2003). Moreover, x-rays induced intracellular reactive oxygen species $\left(\mathrm{ROS}_{\mathrm{i}}\right)$ production, DNA fragments, expression of p53 and apoptosis in MOLT-4 cells (Sasano et al., 2007). Nowadays, radiation safety is of high concern in any medical procedure. Patient dose measurements will help to optimize radiation protection of the patient. Entrance surface dose is used to estimate patient radiation doses in diagnostic x-ray examinations. There are common dosimeters used to estimate entrance surface doses for patient during radiographic examinations including Dose Area Product (DAP), Thermoluminescent Dosimeter (TLD) and Ionization Chamber (IC). The entrance surface dose and effective dose during barium swallow, barium enema, distal colonogram and micturating cystourethrography have been measured using dose area products (Livingstone et al., 2008). Entrance surface doses of patients undergoing pelvis, abdomen and lumbar spine diagnostic $\mathrm{x}$-ray examinations is measured means of thermoluminescent dosimeter (Ogundare et al., 2004). In addition, ionizing chamber is used to measure entrance surface doses and effective doses for abdomen, chest lumbar spine, lumbo-sacral joint, pelvis, skull and urinary tract x-ray examinations (Compagnone et al., 2006). However, the quantity of entrance surface doses and effective doses cannot be directly measure on the patient during diagnostic $\mathrm{x}$-ray examinations. It has to be calculated.

In this study, we proposed an equation to estimate radiation doses from single phase, three phases and high frequency $\mathrm{x}$-ray machine.

\section{MATERIALS AND METHODS}

General: This study was carried out in three system xray machines that consist of single phase, three phases and high frequency system. The three $\mathrm{x}$-ray machines were performed quality control assessments before experiment. The National Council on Radiation Protection (NCRP) Report No. 99 was used for standard values for quality control.

Corresponding Author: Suchart Kothan, Department of Radiologic Technology, Faculty of Associated Medical Sciences, Chiang Mai University, Chiang Mai 50200, Thailand Tel: +665 3949208 Fax: +665 3949207 
Am. J. Applied Sci., 8 (9): 923-926, 2011

Table 1: Radiation doses from x-ray machine (Source-chamber distance $=100 \mathrm{~cm}$ )

\begin{tabular}{llll}
\hline $\mathrm{kVp}$ setting & mAs setting & Radiation dose; $(\mathrm{mR})$ & $\mathrm{mR} / \mathrm{mAs}$ \\
\hline 50 & 10 & 13.8 & 1.38 \\
60 & 10 & 22.8 & 2.28 \\
70 & 10 & 29.7 & 2.97 \\
80 & 10 & 40.2 & 4.02 \\
90 & 10 & 52.5 & 5.25 \\
100 & 10 & 64.3 & 6.43 \\
110 & 10 & 77.5 & 7.75 \\
120 & 10 & 91.7 & 9.17 \\
\hline
\end{tabular}

Table 2: The $\mathrm{n}$ values in Eq. 6

\begin{tabular}{ll}
\hline $\mathrm{kVp}$ setting, $10 \mathrm{mAs}$ & $\mathrm{n}$ (comparison at $120 \mathrm{kVp})$ \\
\hline 50 & 2.2 \\
60 & 2.0 \\
70 & 2.1 \\
80 & 2.0 \\
90 & 1.9 \\
100 & 1.9 \\
110 & 1.9 \\
120 & 2.0 \\
& Average $=2.0$ \\
\hline
\end{tabular}

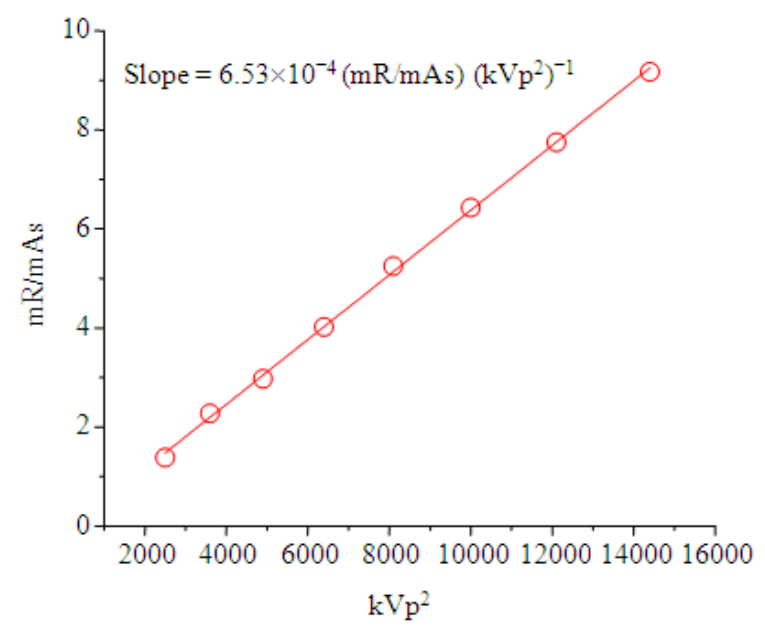

Fig. 1: The relationship between $\mathrm{mR} / \mathrm{mAs}$ and $\mathrm{kVp}^{2}$

Equation for calculation radiation dose: As we knew that the parameters were influence by $\mathrm{x}$-ray radiation doses from the $\mathrm{x}$-ray machine the equation is as following:

Output (milliRoentgen, $\mathrm{mR}$ ) $\alpha \mathrm{kVp}$

$\alpha \quad \mathrm{mA}$

$\alpha \quad s$

$\alpha \quad 1 / d^{2}$

where, $\mathrm{kVp}$ was the peak tube voltage, $\mathrm{mA}$ was the current supply to the tube, $\mathrm{s}$ (second) was the exposure time, $\mathrm{d}$ was the distance, $\mathrm{n}$ was the constant value.
Eq. 1-4 was written as follows Eq. 5:

Output $(\mathrm{mR})=\mathrm{K} \times \mathrm{kVp}^{\mathrm{n}} \times \mathrm{mA} \times \mathrm{s} \times\left(1 / \mathrm{d}^{2}\right)$

where, $\mathrm{K}$ was the constant value which was the slope of the line between $\mathrm{mR} / \mathrm{mAs}$ and $\mathrm{kVp}^{2}$. $\mathrm{d}$ was fixed. This was written as follows:

Output $(\mathrm{mR})=\mathrm{K} \times \mathrm{kVp} \mathrm{p}^{\mathrm{n}} \times \mathrm{mA} \times \mathrm{s}$

Measurement of radiation doses using ionizing chamber dosimetry: The system of radiation dose measurement was setup. The source-chamber distance was $100 \mathrm{~cm}$. The radiation dose was recorded as a function of $\mathrm{kVp}$ (fix $10 \mathrm{mAs}$ ) as indicated in Table 1.

Calculation of $\mathbf{n}$ value in Eq. 6: To calculate the $n$ value, each radiation dose from Table 1 was related into Eq. 6 and compared with $120 \mathrm{kVp}$. An example of the $n$ value determination was as follows.

From (6):

Output $(\mathrm{mR})=\mathrm{K} \times \mathrm{kVp} \mathrm{p}^{\mathrm{n}} \times \mathrm{mAs}$

At $80 \mathrm{kVp}$ the Output was $40.2 \mathrm{mR}$ and was written as Eq. 7:

$40.2 \mathrm{mR}=\mathrm{K} \times(80 \mathrm{kVp})^{\mathrm{n}} \times 10 \mathrm{mAs}$

At $120 \mathrm{kVp}$ the Output was $91.7 \mathrm{mR}$ and was written as Eq. 8:

$91.7 \mathrm{mR}=\mathrm{K} \times(100 \mathrm{kVp})^{\mathrm{n}} \times 10 \mathrm{mAs}$

From (7) and (8):

$$
\begin{aligned}
& \frac{40.2 \mathrm{mR}}{91.7 \mathrm{mR}}=\frac{\mathrm{K}}{\mathrm{K}}\left(\frac{80 \mathrm{kVp}}{120 \mathrm{kVp}}\right)^{\mathrm{n}} \frac{10 \mathrm{mAs}}{10 \mathrm{mAs}} \\
& \mathrm{n}=2.0
\end{aligned}
$$

The $\mathrm{n}$ values in Eq. 6 were indicated in Table 2. The average $n$ value was 2 .

Determination of $\mathbf{K}$ value in Eq. 6: To determine $K$ values, $\mathrm{mR} / \mathrm{mAs}$ was plotted as a function of $\mathrm{kVp}^{2}$ that was indicated (Fig. 1). The slope of the plotted $\mathrm{mR} / \mathrm{mAs}$ as a function of $\mathrm{kVp}^{2}$ represents the $\mathrm{K}$ value. We found that the $\mathrm{K}$ value equaled $6.53 \times 10^{-4}$ $(\mathrm{mR} / \mathrm{mAs})\left(\mathrm{kVp}^{2}\right)^{-1}$. Finally, the equation for calculating radiation doses was as follows Eq. 9:

$\operatorname{Output}(\mathrm{mR})=6.53 \times 10^{-4}(\mathrm{mR} / \mathrm{mAs})$

$\left(\mathrm{kVp}^{2}\right)^{-1} \times \mathrm{kVp} \mathrm{p}^{2} \times \mathrm{mAs}$ 
The equation for single phase, three phases and high frequency $x$-ray machines: The pulse of current affected the radiation output. This means that the equation should also calculate a current pulse factor. The factor of single phase, three phases and high frequency were $0.5,0.8$ and 1.0 , respectively. The equations were as follows.

For the single phase $\mathrm{x}$-ray machine:

$$
\begin{aligned}
& \operatorname{Output}(\mathrm{mR})=0.5 \times 6.53 \times 10^{-4} \\
& (\mathrm{mR} / \mathrm{mAs})\left(\mathrm{kVp}^{2}\right)^{-1} \times \mathrm{kVp}^{2} \times \mathrm{mAs}
\end{aligned}
$$

For the three phases x-ray machine:

$$
\begin{aligned}
& \operatorname{Output}(\mathrm{mR})=0.8 \times 6.53 \times 10^{-4} \\
& (\mathrm{mR} / \mathrm{mAs})\left(\mathrm{kVp}^{2}\right)^{-1} \times \mathrm{kVp}^{2} \times \mathrm{mAs}
\end{aligned}
$$

For the high frequency $x$-ray machine:

$$
\begin{aligned}
& \operatorname{Output}(\mathrm{mR})=1.0 \times 6.53 \times 10^{-4} \\
& (\mathrm{mR} / \mathrm{mAs})\left(\mathrm{kVp}^{2}\right)^{-1} \times \mathrm{kVp}^{2} \times \mathrm{mAs}
\end{aligned}
$$

\section{RESULTS}

To compare the measured radiation dose from ionizing chamber dosimetry with calculated radiation dose Eq. 10 was used in single phase $\mathrm{x}$-ray machine.

Figure 2 indicates the radiation dose from measurement and calculation for single phase $\mathrm{x}$-ray machine. The result showed that the measured radiation dose was not different to calculated radiation dose, using Eq. 10 in single phase $\mathrm{x}$-ray machine.

To compare the measured radiation dose from ionizing chamber dosimetry with the calculated radiation dose Eq. 11 was used in three phases $\mathrm{x}$ ray machine.

Figure 3 indicates the radiation dose from measurement and calculation for three phase $\mathrm{x}$-ray machine. The measured radiation dose was similarly to the calculated radiation dose, using Eq. 11 in three phases x-ray machine.

To compare the measured radiation dose from the ionizing chamber dosimetry with the calculated radiation dose Eq. 12 was used in the high frequency $x-$ ray machine.

Figure 4 indicated that the radiation dose from measurement and calculation for high frequency $\mathrm{x}$-ray machine. It was shown that the measured radiation dose was similarly to calculated radiation dose using Eq. 12 in the high frequency $x$-ray machine.

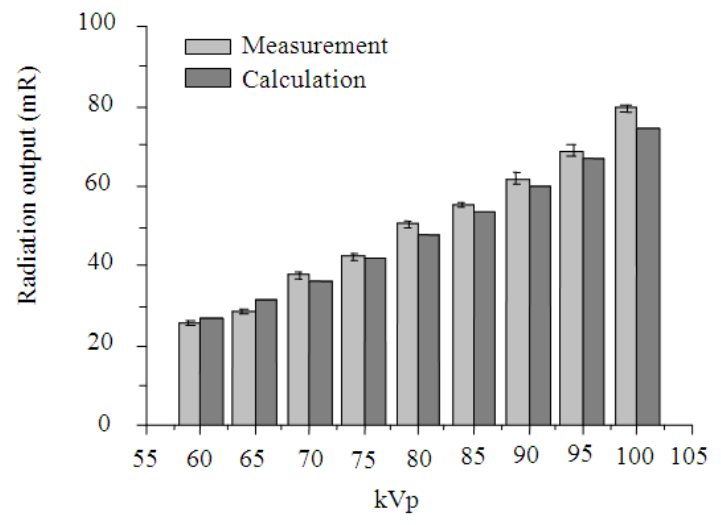

Fig. 2: The comparison of radiation dose from measurement and calculation for single phase x-ray machine

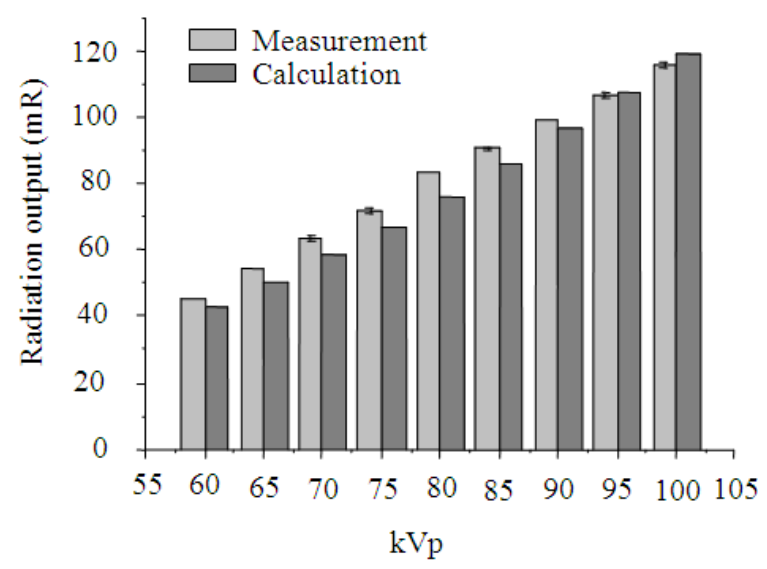

Fig. 3: The comparison of radiation dose from measurement and calculation for three phases $\mathrm{x}$ ray machine

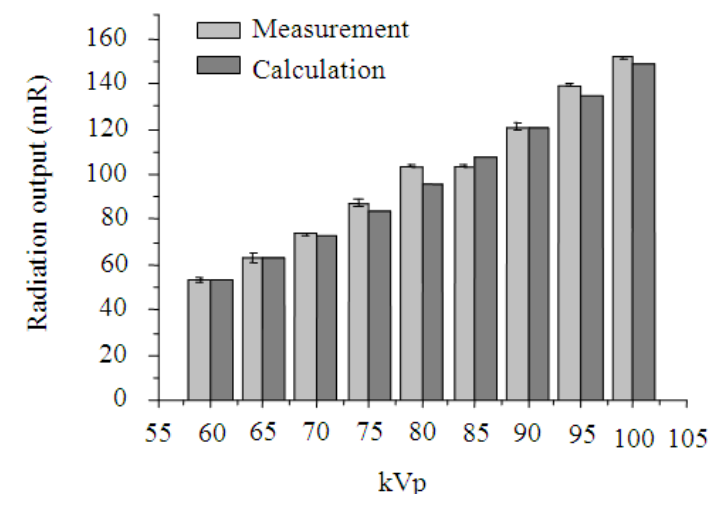

Fig. 4: The comparison of radiation dose from measurement and calculation for high frequency $x$-ray machine 


\section{DISCUSSION}

Several authors had estimated the patient radiation dose in diagnostic x-ray medicine through mathematical or computer calculations. The entrance skin dose was calculated using mathematical models for patient undergoing examinations of the chest, skull, lumbar spine, abdomen, intravenous urogram and pelvis (Halato et al., 2008). In this study, we proposed the equation to calculate the radiation dose. The radiation dose from calculations using our equation was similarly to the measurement as indicated in the results. This suggests consistency with the report of Tsapaki et al. (2007) that the entrance surface dose to patient undergoing chest, abdomen and urinary tract examinations from mathematical calculation and thermoluminescent dosimeter were shown very small different. Suliman and Habbani (2007) investigated the estimation of entrance surface doses from x-ray tube output parameters using mathematical models and effective doses from NRPB-SR262 Monte Carlo computer data and Xdose software for chest, skull pelvis and lumbar spine diagnostic $\mathrm{x}$-ray examinations.

\section{CONCLUSION}

Patient radiation doses were very useful in helping with radiation protection of the patient. This study provided an equation to estimate patient radiation dose. The equation, Output $(\mathrm{mR})=\mathrm{A} \times 6.53 \times 10^{-4}$ $(\mathrm{mR} / \mathrm{mAs})\left(\mathrm{kVp}^{2}\right)^{-1} \times \mathrm{kVp}^{2} \times \mathrm{mAs}$, where A was $0.5,0.8$ and 1.0 for single phase, three phases and high frequency $\mathrm{x}$-ray machine, respectively altered the confident and cheap method of patient dose measurement in routine diagnostic $\mathrm{x}$-ray examinations.

\section{REFERENCES}

Compagnone, G., M.C. Baleni, L. Pagan, F.L. Calzolaio and L. Barozzi et al., 2006. Comparison of radiation doses to patients undergoing standard radiographic examinations with conventional screen-film radiography, computed radiography and direct digital radiography. Br. J. Radiol., 79: 899-904. DOI:

$10.1259 / \mathrm{BJR} / 57138583$
Halato, M.A., I.I. Suliman, S.T. Kafi, A.M. Ahmed and F.A.S. Ahamed et al., 2008. Dosimetry for patients undergoing radiographic examinations in sudan. Proceedings of the 9th Radiation Physics and Protection Conference, Nov. 15-19, Nasr City, Cairo, Egypt, pp: 157-164.

Liu, F.Q. and J.R. Zhang, 2003. X-ray induced L02 cells damage rescued by new anti-oxidant NADH. World J. Gastroenterol., 9: 1781-1785. PMID: 12918120

Livingstone, R.S., A. Eapen and G.K. Chiramel, 2008. Radiation dose to paediatric patients undergoing fluoroscopic examinations performed using digital imaging system. Radiography, 14: 17-23. DOI: 10.1016/J.RADI.2006.06.004

Ogundare, F.O., C.Z. Uche and F.A. Balogun, 2004. Radiological parameters and radiation doses of patients undergoing abdomen, pelvis and lumbar spine X-ray examinations in three Nigerian hospitals. Br. J. Radiol., 77: 934-940. DOI: 10.1259/BJR/55841517 PMID: 15507418

Sasano, N., A. Enomoto, Y. Hosoi, Y. Katsumura and Y. Matsumoto et al., 2007. Free radical scavenger edaravone suppresses $\mathrm{X}$-ray-induced apoptosis through p53 inhibition in MOLT-4 cells. J. Radiat. Res. (Tokyo), 48: 495-503. DOI: 10.1269/JRR.07061 PMID: 17965547

Suliman, I.I. and F.I. Habbani, 2007. Effective Dose Calculations in Conventional Diagnostic X-Ray Examinations for Patients in Major Sudanese Hospitals. World Cong. Med. Phys. Biomed. Eng., 14: 2087-2091. DOI: 10.1007/978-3-540-36841$0 \_526$

Tahara, S. and T. Kaneko, 2004. Susceptibility of mouse splenic cells to oxidative DNA damage by x-ray irradiation. Biol. Pharm. Bull., 27: 105-105. DOI: 10.1248/BPB.27.105

Tsapaki, V., I.A. Tsalafoutas, I. Chinofoti, A. Karageorgi and E. Carinou et al., 2007. Radiation doses to patients undergoing standard radiographic examinations: A comparison between two methods. Br. J. Radiol., 80: 107-112. DOI: 10.1259/BJR/87150291 PMID: 16885174 